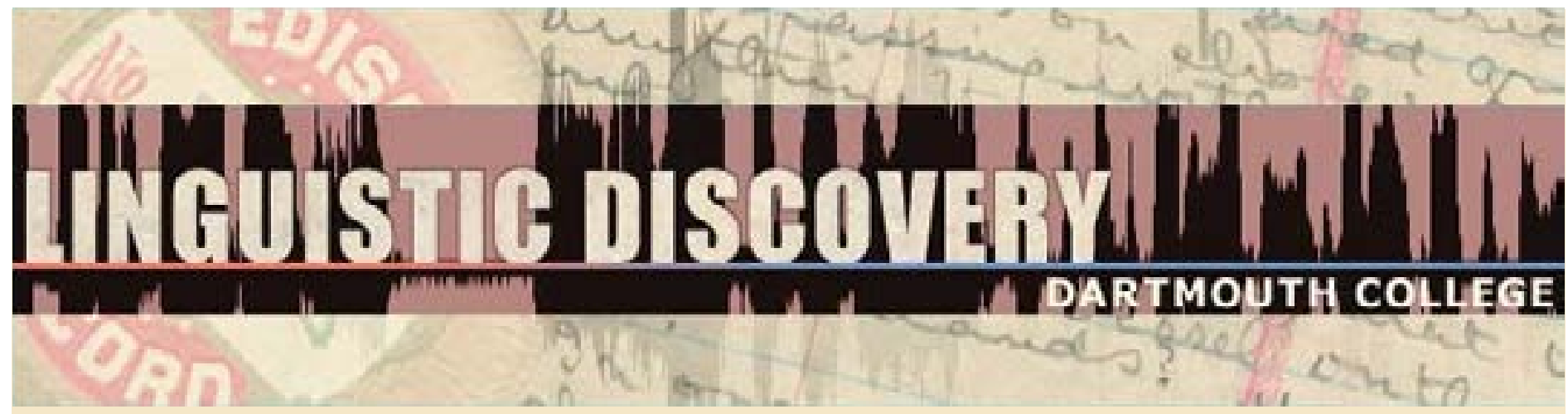

Volume 10

Issue 3

2012

\section{The Expression of Three-Participant Events in Movima}

Katharina Haude

CNRS (SeDyL-CELIA, UMR 8202)

doi: 10.1349/PS1.1537-0852.A.417

url: http://journals.dartmouth.edu/cgi-bin/WebObjects/ Journals.woa/1/xmlpage/1/article/417
Linguistic Discovery

Published by the Dartmouth College Library Copyright to this article is held by the authors. ISSN 1537-0852 linguistic-discovery.dartmouth.edu 


\section{The Expression of Three-Participant Events in Movima Katharina Haude \\ CNRS (SeDyL-CELIA, UMR 8202)}

In Movima (isolate, Amazonian Bolivia), the structure of transitive clauses is determined by referential properties of the core arguments: the encoding of an argument depends on the position of its referent on a referential hierarchy. Movima has no ditransitive constructions. Three-participant events are expressed by monotransitive clauses, with one of the non-Agent participants having the status of an argument and the other that of an adjunct. In threeparticipant clauses there are no reference effects, i.e., there is no competition for argument status between the two non-Agent participants based on relative referential properties. Instead, the choice of which non-Agent participant is encoded as an argument and which as an adjunct is determined by the lexical or derivational properties of the predicate.

\section{Introduction}

This paper investigates the expression of three-participant events in Movima, an endangered, genetically unclassified language spoken in the Bolivian Beni department. In Movima, transitive clauses are organized according to a referential hierarchy that involves person $(1>2>3)$ and topicality (topical > nontopical): the position on the hierarchy of a referent determines the way in which the arguments are encoded. The higher-ranking referent is obligatorily expressed by an argument that is represented by a pronoun or NP immediately following the predicate and phonologically attached to it. The lower-ranking referent is not obligatorily expressed; when it is, it is represented in second position after the predicate by a pronoun or NP that is not, or less tightly, phonologically attached to the preceding constituent (i.e., the predicate with the referentially higher-ranking argument). Direct and inverse morphology on the verb indicates which of the two participants is the actor and which one is the undergoer.

There are no ditransitive predicates in Movima, i.e., predicates that take three syntactic arguments. There are, however, verbs that can be characterized as three-participant event expressions because they denote events that involve three participants: an Agent (A), a Theme (T), and a Goal (G; see Bickel 2010: $402-403$ and Witzlack-Makarevich et al.). With such predicates, one of the two non-Agent participants is expressed as an argument and the other one as an adjunct. Depending on which non-Agent participant is expressed in which way, I refer to a given verb as either indirective or secundative (Haspelmath 2005, following Dryer 1986): a verb that takes $\mathrm{T}$ as its argument is called indirective, and a verb that takes $\mathrm{G}$ as its argument is called secundative; note, however, that in contrast to the original application of the terms, Movima has no indirect or secondary syntactic argument, because the corresponding participants ( $\mathrm{G}$ or $\mathrm{T}$, respectively) are expressed as adjuncts.

As will be shown, the referential hierarchy does not influence the choice of which of the participants is encoded as argument and which as adjunct: this depends on the lexical properties of the verb. When a verb is derived by benefactive, malefactive, applicative, or causative morphemes, the argument frame (indirective or secundative) is determined by the derivational morpheme; an additional applicative affix can reverse the argument frame of a derived verb without showing, however, any reference effects either. A third participant can also be represented by an incorporated nominal element or classifier, which can be either G or T, leaving the remaining non-Agent participant to be expressed as an argument. 
The paper is organized as follows. Section 2 provides the basis of Movima transitive clause structure; it describes argument encoding and the reference effects that are manifested there (2.1) and gives an overview of the formal and functional properties of adjuncts (2.2). Section 3 describes the characteristics of verbs expressing three-participant events, which are labeled either secundative (3.1) or indirective (3.2), depending on which of the two non-Agent participants is encoded as an argument and which one as an adjunct. Derived three-participant verbs are described in 3.3 .

The present paper, far from being exhaustive, is an initial outline of the way in which threeparticipant events are expressed in Movima. A detailed analysis of the lexicon and a frequencybased study of the expression of event participants still remain to be carried out. ${ }^{1}$

\section{Transitive Clauses and Reference Effects}

\subsection{Argument encoding}

Movima transitive clauses contain maximally two arguments, labeled proximate argument (PROX) and obviative argument (OBV; see below for justification of the terms), of which only one, PROX, is obligatorily overtly encoded. There is no agreement morphology on the verb. The structure of a canonical transitive clause is schematized in (1): the predicate (PRED) is the first constituent in a canonical transitive clause, optionally preceded by a free pronoun or NP in topic position; it is followed by the two arguments, realized as NPs or bound pronouns, of which only the first one (PROX) is obligatorily realized; adjuncts (ADJCT) usually come towards the end of the clause. Particles can occur anywhere in the clause (see Haude 2006: 501ff.) and are not represented here.

\section{(1) (TOP) PRED PROX (OBV) (ADJCT)}

The two arguments are formally distinguished not only by their linear order but also, among other things, by the respective cliticization processes in which they are involved. Their different properties are listed in Table 1 (see Haude 2010 for a more detailed account).

\begin{tabular}{|c|c|}
\hline PROX & OBV \\
\hline $\begin{array}{l}\text { internal cliticization }(=) \text { : stress shift, } \\
\text { epenthetic /a/ on consonant-final hosts } \\
\text { pronouns and articles are cliticized } \\
\text { obligatory }^{2}\end{array}$ & $\begin{array}{l}\text { external cliticization ( -- ): no stress shift; no } \\
\text { epenthetic /a/; resyllabification with } \\
\text { consonant-final host } \\
\text { only pronouns are cliticized } \\
\text { not grammatically obligatory }\end{array}$ \\
\hline
\end{tabular}

Table 1: Formal properties of PROX and OBV

\footnotetext{
${ }^{1}$ The paper was prepared within the EuroBABEL project "Referential Hierarchies in Morphosyntax" (DFG HA 5910/1-1). It is written in memory of Anna Siewierska, who has pointed out the importance of investigating threeparticipant constructions in inverse systems. I wish to thank Eva van Lier and an anonymous reviewer for their valuable comments. The paper is based on a corpus of text and elicitation data collected between 2001 and 2010 in Santa Ana del Yacuma, Bolivia, and I am deeply grateful to the Movima speakers who had the patience of teaching me their language.

${ }^{2}$ I.e., the PROX enclitic cannot be omitted; the absence of an overt element (i.e. $\left.=\varnothing\right)$, unambiguously marks the first person singular (see Haude 2010).
} 
The labels PROX and OBV are shorthand terms for proximate and obviative argument. They are borrowed from the Algonquianist terminology, where they indicate the morphologically marked difference between two third-persons. My use of the terms for Movima (introduced by Bickel 2010) intends to reflect the fact that the encoding of an event participant as either one or the other argument depends on its referential properties: the participant ranking higher in the hierarchies of person $(1 \mathrm{sg} / \mathrm{pl}>2 \mathrm{sg}>2 \mathrm{pl}>3)$ and topicality ( 3 topical $>3$ nontopical) is encoded as PROX, and the participant ranking lower on these hierarchies is encoded as OBV. ${ }^{3}$ This is reflected as follows: the first person singular/plural and the second person singular can only be expressed as PROX; the second person plural, if interacting with the first person, is expressed as OBV; a third person is expressed as OBV when interacting with a first or second person or with a more topical third person; it is only expressed as PROX when interacting with another, less topical third person (on deviations, see Haude 2010 and Haude 2012). The possibilities of person encoding are listed in (2).

\begin{tabular}{|c|c|c|}
\hline (2) & PROX & OBV \\
\hline & $1 \mathrm{SG} / \mathrm{PL}$ & 2PL, 3 \\
\hline & $2 \mathrm{SG} / \mathrm{PL}$ & 3 \\
\hline & 3 topical & 3 nontopical \\
\hline
\end{tabular}

The roles of the two arguments of a transitive clause are indicated by a direct or inverse marker on the predicate, which indicates which argument represents the actor (i.e., Agent) and which one represents the undergoer (or non-Agent, i.e. Patient (P), Theme (T), or Goal $(\mathrm{G})$ ). ${ }^{4}$ When PROX is the actor and OBV the undergoer, then the verb is overtly marked as direct; when PROX is the undergoer and OBV the actor, then the verb is overtly marked as inverse. This is illustrated in the examples below for scenarios involving a third person (for scenarios involving first and second person, see Haude 2011).

$1^{\text {st }}$ actor, $3^{\text {rd }}$ undergoer: direct

(3) sal-na $=\varnothing-$-us

search_for-DR=1SG-3M.AB

'I look for him.'

$1^{\text {st }}$ undergoer, $3^{\text {rd }}$ actor: inverse

(4) sal-kay $=\varnothing$--us

search_for-INV=1SG-3M.AB

'He looks for me.'

\footnotetext{
${ }^{3}$ Animacy, or, more precisely, the opposition human vs. non-human, does not play a primary role in the hierarchy. While in most scenarios with a human and a non-human participant, the human participant is treated as higherranking, animacy is easily overruled by other factors (see Haude 2010).

${ }^{4}$ See Van Valin and LaPolla 1997. Since direct and inverse marking makes no distinction between the more finegrained semantic roles (Patient, Theme, Goal) of non-agents, it is convenient for the description of Movima transitive predicates to use the macrorole terms from Role and Reference Grammar.
} 
$2^{\text {nd }}$ actor, $3^{\text {rd }}$ undergoer: direct

(5) sal-na $=$ n--us

search_for-DR=2SG--3M.AB

'You look for him.'

$2^{\text {nd }}$ undergoer, $3^{\text {rd }}$ actor: inverse

(6) sal-kay-a =n--us

search_for-INV-LV=2SG--3M.AB

'He looks for you.'

$3^{\text {rd }}$ (topical) actor, $3^{\text {rd }}$ (nontopical) undergoer: direct

(7) sal-na $=$ us--kus

search_for $=3 \mathrm{M} \cdot \mathrm{AB}--3 \mathrm{M} \cdot \mathrm{AB}: \mathrm{OBV}{ }^{5}$

'He looks for him.'

$3^{\text {rd }}$ (topical) undergoer, 3 (nontopical) actor: inverse

(8) sal-kay-a = us--kus

search_for-LV=3M.AB--3M.AB:OBV

'He looks for him.'

The text examples below further illustrate the employment of the direct (9) and inverse (10) morphemes in third-person scenarios. In (9), the two event participants are plural third persons. In (9a), the PROX pronoun $=i s$ 'they' refers to participants (the speaker's ancestors) that are already known from the context; the possessed NP is majniwa=is 'their children' introduces a new participant and accordingly is encoded as OBV; the topical referent being the actor and the nontopical referent the undergoer, the predicate is marked as direct. In (9b), the situation is the same, apart from the fact that both participants are now represented by pronouns; the more topical one is encoded as PROX and the less topical as OBV. Note that a bound pronoun representing OBV is externally cliticized to the predicate (marked by a double hyphen -- ); when, as in this case, both pronouns encode a third person, the OBV pronoun furthermore contains the obviative marker $k$ - (see also (7) and (8) above).
a. jayna
DSC
jay $<$ a $>$ mok- $\mathrm{a}=$ is
call $<\mathrm{DR}>-\mathrm{LV}=3 \mathrm{PL} . \mathrm{AB}$
is $\quad$ majniwa $=$ is
ART.PL child_of=3PL.AB
b. che $\quad$ ken $<\mathbf{a}>$ pa $=$ is--kis
and inform $\langle$ DR $>=3$ PL.AB--3PL.AB:OBV
'Then they $\mathrm{y}_{\mathrm{i}}$ called their $\mathrm{i}_{\mathrm{i}}$ children $_{\mathrm{j}}$ and informed them $\mathrm{j}_{\mathrm{j}}$.'

In (10), the situation is the same as above: the topical participant is expressed by a pronoun and the newly introduced participant by a NP. The former is encoded as PROX and the latter as

\footnotetext{
${ }^{5}$ When two third persons interact, an OBV pronoun contains an element $k$-, which I analyze as a redundant obviative marker (see Haude 2006: 279-280).
} 
OBV. Here, the topical participant is the undergoer, as is indicated by the inverse marking on the predicate.

$\begin{array}{llll}\text { jayna } & \text { dewaj-kay-a }=\text { us } & \text { isnos } & \text { alwaj-a }=\text { us } \\ \text { DSC } & \text { see-INV-LV=3M.AB } & \text { ART.F.PST } & \text { spouse-DR=3M.AB }\end{array}$

'Then his wife saw him.'

As mentioned below, the OBV argument is not obligatorily overtly expressed. When known from the context, it is easily omitted, as illustrated in (11) (more examples will follow in Section $3)$.

$\begin{array}{lllll}\text { (11) jayna } & \text { mat-pit-chef--us } & \text { tat, } & \text { mas-na }=\text { us } & \text { jayna } \\ \text { DSC } & \text { loosen-CL.middle-R/R--3M.AB } & \text { EV } & \text { beat-DR=3M.AB } & \text { DSC }\end{array}$

'Then he took off his belt, he beat (her).'

Finally, a core argument can also be expressed by a free pronoun in topic (i.e. pre-predicate) position, rather than by a post-predicate pronoun or NP. When the topicalized free pronoun corresponds to OBV (the most common case), as in (12), it replaces the OBV NP/pronoun. When it corresponds to PROX, as in (13), PROX is still additionally encoded by the obligatory enclitic element.

$$
\begin{array}{lll}
\text { asko } & \text { rim }<\mathrm{a}>\mathrm{te}=\text { 'nes } & \text { ma:mi } \\
\text { PRO.N.AB } & \text { sell } \angle \mathrm{DR}>=\text { ART.3F } & \text { mum }
\end{array}
$$

'That (was what) my mother sold.'

$\begin{array}{ll}\text { (13) U'ko } & \text { invitar-na }=\text { u--kisne } \\ \text { PRO.M } & \text { invite-DR=3M--3F.AB:OBV } \\ \text { 'He invited her.' }\end{array}$

\subsection{Adjuncts}

Any additional participant is encoded as an adjunct, overtly marked by the oblique prefix $n$ - $(n V$ before consonants). An adjunct is never grammatically obligatory and can in principle occur with any verb; also, there seem to be no restrictions on its semantic role. To illustrate this, examples (14)-(18) show intransitive clauses where the adjunct denotes a location (14), an instrument (15), an instrument or agent (16), a point in time (17), and a patient (18).

$\begin{array}{llll}\begin{array}{l}\text { a:lalas } \\ \text { always }\end{array} \text { go-R/R } & \text { n-as } & \text { ele:siya } \\ \text { church }\end{array}$


$\begin{array}{llll}\text { didi } & \text { tikoy-cheł } & \text { n-os } & \text { kachi:ra } \\ \text { FRUST } & \text { kill-R/R } & \text { OBL-ART.N.PST } & \text { knife }\end{array}$

'(He) wanted to kill himself with a knife.'

bił-'i is

scratch-RES ART.PL

$$
\text { dinoj-a }=\text { 'ne }
$$

$\mathrm{n}$-is

alamre

'Her legs were scratched from the fence.'

$\begin{array}{llll}\text { dewaj-na }=\mathrm{n} & \text { n-as } & \text { i:may } & \text { ja'a } \\ \text { see-DR=2 } & \text { OBL-ART.N } & \text { night } & \text { just }\end{array}$

'You only see it at night.'

$$
\begin{array}{lll}
\text { rał-pit-e:łe } & \mathbf{n} \text {-is } & \text { kade:na } \\
\text { tear-CL.half-AGT } & \text { OBL-ART.PL } & \text { chain }
\end{array}
$$

'(It) tore the chain (and escaped).'

Adjuncts in transitive clauses are illustrated in (19) and (20). In the direct clause (19), the adjunct denotes a location, and in the inverse clause (20) it represents a purposive adverbial clause (which, in turn, contains a locative adjunct).

$\begin{array}{lllll}\text { ona-ye-na }=\text { sne } & \text { kis } & \text { juyeni } & \text { n-as } & \text { Tirinra } \\ \text { know-CL.person-DR=3F.AB } & \text { ART.PL.AB } & \text { person } & \text { OBL-ART.N } & \text { Trinidad }\end{array}$

'She knows people in Trinidad.'

$\begin{array}{lllll}\text { invitar-kay }=\varnothing \text {--is } & \text { n-os } & \text { joy-wa }=\varnothing & \text { n-os } & \text { velo:riyo } \\ \text { invite-INV=1SG--3PL.AB } & \text { OBL-ART.N.PST } & \text { go-NMZ=1SG } & \text { OBL-ART.N.PST } & \text { wake }\end{array}$

'They invited me to go to the wake.'

One often finds clauses that contain an adjunct but no OBV argument, as illustrated in (21). This, however, does not mean that the oblique-marked phrase has an argument status and replaces OBV; rather, the OBV argument is known from the context and simply omitted (see (11) above). More examples will be provided in the following sections.
bat-na $=$ is
n-os
ba $<$ kwa $>$ kwa $=$ isnos
Ana
put-DR=3PL.AB
OBL-ART.N.PST
head $\langle$ INAL $>=$ ART.F.PST
Ana
'They put (it) on Ana's (i.e., the statue's) head.'

\section{The Expression of Three-Participant Events}

Movima has no ditransitive verbs, i.e., verbs that take more than two arguments. Verbs expressing three-participant events can only be identified by their meaning: they denote events that involve causal entailment relations between three participants (see Witzlack-Makarevich et al. in prep.; Margetts and Austin 2007). Some verbs show overt morphology (e.g. applicative, causative, incorporation) that establishes a third participant. Since a Movima clause has only two 
argument positions, only one of the two non-Agent (non-A) participants, i.e. T or G, is expressed as argument, while the other one is optionally expressed as adjunct (an oblique/adjunct strategy, see Margetts and Austin 2007). The question is which non-Agent participant is expressed in which way.

Given that argument encoding in transitive clauses is determined by a referential hierarchy in Movima, it might be expected that this hierarchy also determines the choice of the non-A argument in three-participant expressions, in the sense that the highest-ranking one of the $\mathrm{T}$ and $\mathrm{G}$ participants will be selected as argument. However, referential factors do not play a role here. This is illustrated by the elicited examples (22) and (23) below. The verb kayate 'give' takes G as the core argument, and it does this independently of the relative hierarchical status of the nonA participants. In both examples, $T$ (first person plural) hierarchically outranks $\mathrm{G}$ (third person plural). However, $\mathrm{T}$ is always encoded as an adjunct ( $n$-iy'fi) and $\mathrm{G}$ as an argument (OBV --is in (22), PROX =nkwet in (23)). The voice marking of the predicate, direct in (22) and inverse in (23), depends exclusively on the hierarchical relationship between the two arguments, A and, here, $\mathrm{G}$.

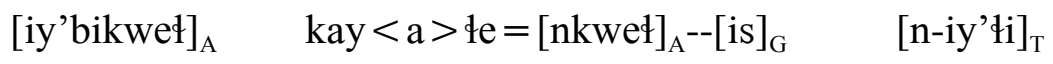

PRO.2PL give $\langle$ DR $>=2 P L-3 P L . A B \quad$ OBL-PRO.1PL

You (pl.) have given us to them.'

$$
\begin{array}{lll}
{[\text { isko }]_{\mathrm{A}}} & \text { kay-łe-kay-a }=\left[\mathrm{nkwet}_{\mathrm{G}}\right. & {[\mathrm{n} \text {-iy'ti }]_{\mathrm{T}}} \\
\text { PRO.3PL } & \text { give-DR-INV-LV }=2 \mathrm{PL} & \text { OBL-PRO.1PL }
\end{array}
$$

'They have given us to you (pl.).'

Even without direct reference effects, for a language like Movima whose transitive constructions are primarily organized according to referential properties of the arguments, it is expected to find predominantly or exclusively $\mathrm{G}$ encoded as the argument of a three-participant expression, since at least in the case of a transfer event the Goal typically ranks higher than the Theme (see Malchukov et al. 2010: 44). In Movima, however, the choice of the participant encoded as argument is lexically or morphologically determined. This will be shown in the following sections. Since the relative referential properties of $\mathrm{T}$ and $\mathrm{G}$ do not play a role in the assignment of the non-A participants to argument versus adjunct status, for the sake of simplicity most examples given here represent the direct construction, and verbs are cited in the direct form.

\subsection{Secundative verbs $(A+G, n-T)$}

The verbs in (24) take the $G$ participant as core argument. Some of these verbs show morphological complexity, as is indicated by the glosses; I will get back to this in Section 3.3. In the translations, the semantic element corresponding to the $\mathrm{T}$ participant is represented in brackets. 


$\begin{array}{lll}\text { kay }<\text { a: }>\text { de } & \text { 'give }<\text { DR }> & \text { 'give (sth.) to sb.' } \\ \text { chut-a-cho:pa } & \text { 'stick-DR-hand' } & \text { 'give (sth.) into sb.'s hands' } \\ \text { baw-a:-ra } & \text { 'cost-DR-CL.thing' } & \text { 'pay sb. (with/for sth.)' } \\ \text { chus-a:-pa } & \text { 'point-DR-APPL' } & \text { 'show (sth./sb.) to sb.' } \\ \text { vat-a:-pa } & \text { 'appear-DR-APPL' } & \text { 'teach sb. (sth.)' } \\ \text { daj }<\text { a: }>\text { wa } & \text { 'ask<DR }> & \text { 'ask sb. (sth.)' } \\ \text { suy-na } & \text { 'deprive-DR' } & \text { 'deprive sb. (of sth.)' }\end{array}$

Argument encoding with these verbs is exactly as with other transitive verbs: the encoding as PROX and OBV depends on the referential hierarchy; neither OBV nor the adjunct are obligatorily overtly realized. This is illustrated in the following examples, again with the verb kayate 'give'. ${ }^{6}$ (In all examples of three-participant clauses, square brackets mark the nominal constituents, with subscripts indicating the semantic roles A, T, and G.) In (25) and (26), both non-Agent participants are overtly expressed. The predicate in (25) is marked as direct, indicating that the PROX argument is the actor and the OBV argument the undergoer (i.e., G). In (26), the predicate is marked as inverse, indicating that PROX is the undergoer (G) and OBV the actor. In both examples, the $\mathrm{T}$ participant is expressed by an oblique phrase.

$\begin{array}{llll}\begin{array}{l}\text { jan } \\ \text { that's_why }\end{array} & \begin{array}{l}\text { n-os } \\ \text { OBL-ART.N.PST }\end{array} & \begin{array}{l}\text { kay<a }>\text { ke-na }=[\text { is } \\ \text { give<DR>-NMZ.REAS=ART.PL }\end{array} & \begin{array}{l}\text { juyeni }]_{\mathrm{A}} \\ \text { person }\end{array} \\ \begin{array}{llll}\text { ['neł } & \text { ma:ma }=\mathrm{n}]_{\mathrm{G}} & \begin{array}{l}\text { [n-is } \\ \text { OBL-ART.PL }\end{array} & \text { wa:ka }]_{\mathrm{T}} \\ \text { ART.F } & \text { mother_of=2 } & \text { cow }\end{array}\end{array}$

'That's why the people gave our mother the cattle.'

\begin{tabular}{|c|c|c|c|c|}
\hline $\begin{array}{l}\text { ban } \\
\text { but }\end{array}$ & $\begin{array}{l}\text { di:ra } \\
\text { at_least }\end{array}$ & $\begin{array}{l}\text { kinos } \\
\text { ART.F.AB }\end{array}$ & $\begin{array}{l}\text { virjen, } \\
\text { virgin }\end{array}$ & $\begin{array}{l}\text { kayle-kay-a }=[\mathrm{sne}]_{\mathrm{G}} \\
\text { give-INV-LV=3F.AB }\end{array}$ \\
\hline as & $\begin{array}{l}\text { alkaldiya }]_{A} \\
\text { city_hall }\end{array}$ & $\begin{array}{l}\text { [n-os } \\
\text { OBL-ART.N.PST }\end{array}$ & $\begin{array}{l}\text { kay-wanra }]_{T} \\
\text { eat-INSTR }]_{T}\end{array}$ & \\
\hline
\end{tabular}

'But at least (to) the virgin (Holy Anne), the mayor gave her food.'

In (27), the predicate is nominalized, forming the head of a subordinate clause. This clause does not contain an adjunct representing $\mathrm{T}$; the identity of $\mathrm{T}$ (oy-'aro:wa, a weight unit) is inferred from the context, provided by the main clause.

\footnotetext{
${ }^{6}$ The homophony between the initial element kay- of this verb and the inverse suffix -kay can be considered as accidental. There is also no evidence that the verb root kay- 'eat' has anything to do with the verb 'give' (see also note 11 further below).
} 


\begin{tabular}{|c|c|c|c|c|c|}
\hline $\begin{array}{l}\text { way-na }=\text { us } \\
\text { take-DR=3M.AB }\end{array}$ & $\begin{array}{l}\text { is } \\
\text { ART.PL }\end{array}$ & $\begin{array}{l}\text { oy-'aro:wa } \\
\text { two-arroba }\end{array}$ & $\begin{array}{l}\text { bo } \\
\text { so_that }\end{array}$ & $\begin{array}{l}\text { OS } \\
\text { ART.N.PST }\end{array}$ & $\begin{array}{l}\text { kay }<\mathbf{a}>\text { ke-wa }=[\mathrm{us}]_{\mathrm{A}} \\
\text { give }<\mathrm{DR}>-\mathrm{NMZ}=3 \mathrm{M} . \mathrm{AB}\end{array}$ \\
\hline [os & ney & kwe:ya $]_{\mathrm{G}}$ & & & \\
\hline
\end{tabular}

'He took two arrobas in order to give [them] to that woman.'

Example (28) illustrates the case where $\mathrm{T}$ is the only overtly expressed non-A participant, encoded by an adjunct. The example contains a complex sentence with both clauses (main clause, a., and subordinate clause, b.) showing this property.
a. $\quad k a y<a>k e=\left[y^{\prime}{ }^{\prime} i\right]_{\mathrm{A}} \quad$ pe'łełe give $<\mathrm{DR}>=1 \mathrm{PL}$
all
[ni-kis
OBL-ART.PL.AB
animal $=1 \mathrm{PL}$
nono $\left.=y^{\prime} \mathrm{Hi}\right]_{\mathrm{T}}$
b. bo
as
kayłe- $\varnothing-w a=\left[y^{\prime}+i\right]_{\mathrm{G}}$
[no-kos
OBL-ART N AB
bebetkwa $]_{\mathrm{T}}$
so_that
ART.N
give-INV-NMZ=1PL
hide

'We'll give [you] all our animals so that [you] give us the hide.'

Finally, example (29) illustrates the case where neither $\mathrm{T}$ nor $\mathrm{G}$ are overtly expressed, i.e., there is neither an OBV argument nor an adjunct.

$$
\begin{aligned}
& \begin{array}{l}
\mathbf{k a y}<\mathbf{a}>\mathrm{He}=\text { is, } \\
\text { give }<\mathrm{DR}>=3 \mathrm{PL} . \mathrm{AB}
\end{array} \\
& \text { 'They gave (it to them), they handed (it) over (to them). } \\
& \text { stickinto-DR-hand=3PL.AB }
\end{aligned}
$$

These examples show that a verb denoting a three-participant event shows no syntactic properties that distinguish it from a 'normal' transitive verb: neither the adjunct nor the OBV argument is obligatorily expressed overtly, and there is no indication that the adjunct has a syntactic status different from adjuncts in other transitive clauses, like those in (14)-(18) above. Also with three-participant verbs, the adjunct can represent an entity that is not an event participant, as in (30), where the oblique-marked phrase is a temporal adjunct and the $\mathrm{G}$ participant remains unexpressed.

$$
\begin{array}{lllll}
\mathbf{d o j}<\mathrm{a}>\mathrm{ke}=\text { is } & \text { is } & \text { wa:ka } & \text { n-OS } & \text { i:may } \\
\text { steal } \angle \mathrm{DR}>=3 \text { PL.AB } & \text { ART.PL } & \text { cow } & \text { OBL-ART.N.PST } & \text { night }
\end{array}
$$

'They stole the cattle at night.'

The other verbs listed in (24) behave in the same way as kayałe 'give' above, i.e., they take $\mathrm{G}$ as their argument. An illustration is given in (31) and (32) with the monomorphemic verb suyna 'deprive'. In (31), both non-A participants are overtly encoded; in (32), the OBV argument, which would express $\mathrm{G}$, is omitted (the $\mathrm{G}$ participant is only referred to by the possessor enclitic, which also occurs in (31). ${ }^{7}$

\footnotetext{
${ }^{7}$ This strategy (see Margetts and Austin 2007) is not unusual in Movima, but further research is needed here.
} 


$\begin{array}{llllll}\text { (31) jayna } & \begin{array}{l}\text { suy-na }=[\text { is } \\ \text { deprive-DR=ART.PL }\end{array} & \begin{array}{l}\text { ri:ko }]_{\mathrm{A}} \\ \text { rich }\end{array} & \begin{array}{l}\text { buka' } \\ \text { DUR:MOV }\end{array} & \begin{array}{l}\text { is } \\ \text { ART.PL }\end{array} & \begin{array}{l}\text { powre }]_{\mathrm{G}} \\ \text { poor }\end{array} \\ & & & \\ {[\mathrm{n} \text {-is }} & \text { bet'i } \mathrm{i}=\mathrm{is}]_{\mathrm{T}} & & & \\ \text { OBL-ART.PL } & \text { grassland=3PL.AB } & & & \end{array}$

'Then the rich went about taking away the land from the poor.'

$\begin{array}{llll}\text { suy-na }=[\mathrm{i}]_{\mathrm{A}} & {[\text { no-kos }} & \text { tochik } & \text { polata }=\mathrm{i}]_{\mathrm{T}} \\ \text { deprive-DR=3PL } & \text { deprive-DR=3PL } & \text { small } & \text { money }=3 \mathrm{PL}\end{array}$

'They $y_{\mathrm{i}}$ take away their $\mathrm{j}_{\mathrm{j}}$ little bit of money (from them ${ }_{\mathrm{j}}$ ).'

\subsection{Indirective verbs $(A+T, n-G)$}

The list in (33) contains verbs that, from a semantic point of view, can be characterized as typical three-participant expressions. Some seem synonymous with verbs in (24) above. However, the verbs here have the property that they take T, not G, as their argument, while $\mathrm{G}$ is expressed by an adjunct, if at all. In the translations, the hypothetical $\mathrm{G}$ participant is given in brackets.

$\begin{array}{lll}\text { (33) } & \text { 'give-DR' } & \text { 'pass/give sth. (to sb.)' } \\ \text { aj-a-lo:maj } & \text { 'arrange-DR-CL:time' } & \text { 'tell (sb.) about sth.' } \\ \text { daja:ja } & \text { 'ask_for' } & \text { 'ask (sb.) for sth.' } \\ \text { doj<a:> te } & \text { 'steal<DR>' } & \text { 'steal sth. (from sb.)' } \\ \text { koyit-na } & \text { 'envy-DR' } & \text { 'envy (sb.) sth.' } \\ \text { rim }<\text { a: }>\text { te } & \text { 'sell<DR>' } & \text { 'sell sth. (to sb.)' } \\ \text { rimed-na } & \text { 'buy-DR' } & \text { 'buy sth. (from sb.)' } \\ \text { um-a:-ra } & \text { 'send-DR-CL.thing } & \text { 'send sth. (to sb.)' } \\ \text { bat-na } & \text { 'put-DR' } & \text { 'put sth. (onto sth.)' } \\ \text { yeł-na } & \text { 'plunge-DR' } & \text { 'put sth. (into sth. liquid)' }\end{array}$

Example (34) illustrates the argument structure of the verb kwajna 'give, hand over', which seems synonymous with kayate 'give' above, but is much less used and hence, may be semantically more restricted; in this example, all three participants are overtly expressed.

\begin{tabular}{|c|c|c|c|c|c|}
\hline $\begin{array}{l}\mathbf{k w a j - n a}=\left[y^{\prime} \mathrm{H}\right]_{\mathrm{A}} \\
\text { give-DR=1PL }\end{array}$ & $\begin{array}{l}{[\mathrm{kOS}} \\
\text { ART.N.AB }\end{array}$ & $\begin{array}{l}\text { sinko } \\
\text { five }\end{array}$ & $\begin{array}{l}\text { pe:so }]_{\mathrm{T}} \\
\text { peso }\end{array}$ & & \\
\hline $\begin{array}{l}\text { [n-i'nes } \\
\text { OBL-ART.F }\end{array}$ & $\begin{array}{l}\text { kweyninta } \\
\text { owner }\end{array}$ & $\begin{array}{l}\text { n-as } \\
\text { OBL-ART.N }\end{array}$ & $\begin{array}{l}\text { to:mi } \\
\text { water }\end{array}$ & $\begin{array}{l}\text { n-as } \\
\text { OBL-ART.N }\end{array}$ & $\underset{\text { tap }}{\text { gri:fo }]_{G}}$ \\
\hline
\end{tabular}

'We give five pesos to the owner of the tap water (lit., of the water of the tap).' 
In example (35), which illustrates the verb uma:ra 'send', only G is expressed (as adjunct), while the OBV argument is omitted.

$\begin{array}{lllll}\text { uma-ra }=[\mathrm{sne}]_{\mathrm{A}} & \text { nokowa } & {[\text { ni-kis }} & \text { alkakaye }=\mathrm{sne}]_{\mathrm{G}} & \text { nosdé } \\ \text { send-CL.thing=3F.AB } & \text { FUT } & \text { OBL-ART.PL.AB } & \text { relative }=3 \mathrm{~F} . \mathrm{AB} & \text { over_there }\end{array}$

'She'll send (the photos) now to her relatives over there.'

Verbs of putting, like batna 'put sth. (on sth.) or yetna 'put sth. (into sth. liquid)' are indirective, as illustrated in (36) and (37).

$\begin{array}{lllllll}\text { bat-na }=[\mathrm{as}]_{\mathrm{A}} & {[\text { is }} & \text { rey } & \text { lotodi }=\mathrm{as}]_{\mathrm{T}} & {[\mathrm{n} \text {-OS }} & \text { da' } & \text { dudulkwa }]_{\mathrm{G}} \\ \text { put-DR=PRO.N.AB } & \text { ART.PL } & \text { MOD } & \text { testicle=PRO.N.AB } & \text { OBL-ART.N.PST } & \text { DUR.NSTD } & \text { root } \\ \text { 'It (the jaguar ) put its testicles on the root, } 8 & & & \end{array}$

$\begin{array}{lllll}\text { yef-na }=[\varnothing]_{\mathrm{A}} & {[\text { is }} & \text { tas-lo:di }]_{\mathrm{T}} & {[\mathbf{n} \text {-os }} & \text { bote:liya }]_{\mathrm{G}} \\ \text { plunge-DR=1SG } & \text { ART.PL } & \text { three-CL.drop } & \text { OBL-ART.N.PST } & \text { bottle }\end{array}$

'I put three drops into a bottle.'

When looking up the verbs in (33) in the corpus, it turns out that $\mathrm{G}$ is only very rarely overtly expressed. Examples (38)-(40) illustrate the more typical case, where only T is expressed.

$\begin{array}{llll}\text { loy } & \text { aj }<\mathrm{a}>\text { lo:maj }=[\varnothing]_{\mathrm{A}} & {[\text { os }} & \text { kana-wamba }]_{\mathrm{T}} \\ \text { ITN } & \text { tell }<\mathrm{DR}>=1 \mathrm{SG} & \text { ART.N.PST } & \text { ochoó-INSTR:CL.round }\end{array}$

'I'll narrate about the ochoó island.'

\begin{tabular}{|c|c|c|}
\hline & $\begin{array}{l}\left.\mathrm{ma}^{\prime}=\varnothing\right]_{\mathrm{A}} \\
\text { mother }=1 \mathrm{sc}\end{array}$ & motlo:to \\
\hline
\end{tabular}

'My mother bought golden earrings.'

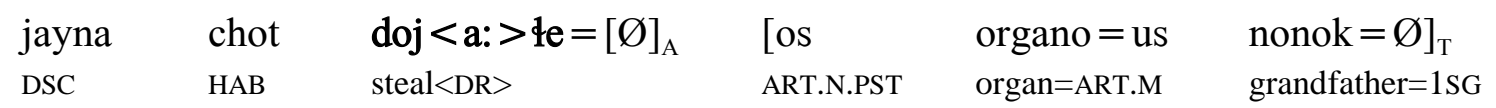

'Then I always stole my grandfather's organ.'

The fact that it is so difficult to find indirective verbs with an adjunct overtly expressing $G$ may be a sign that these verbs are, in fact, two-participant expressions. Maybe they are not correctly interpreted as denoting events with a $\mathrm{G}$ participant. Instead, ajalomaj 'narrate' could mean 'talk about something', without necessarily including an addressee; rimełna 'buy' could mean 'acquire something through exchange', with the source of the acquisition being completely irrelevant; doja:łe 'steal' could mean 'take something without permission', again, without any implication that the original owner might be affected by the event. The idea that there is a $G$ implied may be superimposed by the semantic properties of the - possibly inadequate - English

\footnotetext{
${ }^{8}$ Example (36) is one of the rare examples in the text corpus where the verb batna is accompanied by the overt expression of both non-A participants. It stems from a mythological story about the fox and the jaguar.
} 
translations. If this is true, then the only 'real' three-participant expressions in Movima are secundative verbs. That verbs of putting (see (36) and (37)) are indirective may be due to the fact that their $G$ participant is a location rather than a recipient, in the same way as the locative adjunct of an intransitive verb of directed motion, see (14) above. However, with only a superficial corpus analysis and no detailed (ideally experiment-based) field study, no conclusion can be drawn here.

\subsection{Derived three-participant verbs}

Movima has a large number of valence-increasing morphemes, which increase the number of event participants inherent to the verb's meaning. For the aims of this paper I will focus on the morphemes listed in (41).

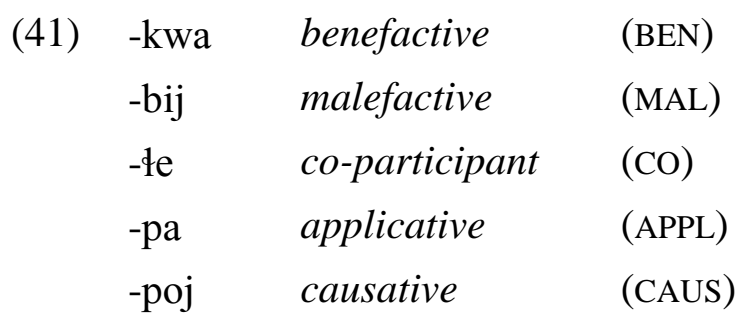

While none of these morphemes can add a third argument, most of them rearrange the syntactic argument structure of the predicate, which takes the applied participant as its argument.

The benefactive and malefactive affixes add a $\mathrm{G}$ participant (the beneficiary or maleficiaryof the event), which is encoded as an argument, while $\mathrm{T}$ is encoded as an adjunct. Examples where both participants are overtly expressed are not easy to find. In (42b), OBV (i.e. G, the beneficiary) is omitted; instead, the possessive pronoun (='ne 'her') is automatically interpreted as the beneficiary. Example (42a) is added to allow a comparison with the syntactic structure of the underived verb, where the OBV argument represents $\mathrm{P}^{9}$
a. ji:sa-na $=[\mathrm{us}$
make-DR=ART.M
itila:kwa] man
[kis
ART.PL.AB
kape-lo $]_{\mathrm{P}}$
'The man makes coffee.'
b. ji:sa-na-kwa-na $=[\text { us itila:kwa }]_{\mathrm{A}}$
make-DR-BEN-DR=ART.M man
[ni-kis
OBL-ART.PL.AB
kape-lo $=$ 'ne $]_{\mathrm{T}}$
coffee-CL.liquid $=3 \mathrm{~F}$
'He makes her coffee (for her),'

In (43), $\mathrm{G}$ is overtly expressed as an argument, but $\mathrm{T}$ is only represented by a classifier (see below).

\footnotetext{
${ }^{9}$ Note that if the verb were inverse, the OBV argument would be A, which shows that a direct comparison in terms of semantic roles is not as straightforward as might be thought.
} 

loy $\quad[i ł]_{\mathrm{A}} \quad$ chi-poj-na-bij-na $=[\varnothing]_{\mathrm{A}}$
[kinoł
ma'a $]_{\mathrm{G}}$
ITN 1 send-DR-CL.hide-BEN-DR=1SG
ART.F.AB.1
my_mother

'I'll send my mother a letter.' 10

Example (44) represents the malefactive construction with both arguments overtly expressed.

$\begin{array}{llllllll}\text { (44) loy } & {[\mathrm{il}]_{\mathrm{A}}} & \text { chi-poj-na-bij-na }=[\varnothing]_{\mathrm{A}} & {[\mathrm{us}} & \text { dichi:ye }]_{\mathrm{G}} & {[\text { no-kos }} & \text { wa:ka-toda }=\mathrm{u}]_{\mathrm{T}} \\ \text { ITN } & 1 & \text { go_out-CAUS-DR-MAL=1SG } & \text { ART.M } & \text { child } & \text { OBL-ART.N.AB } & \text { cow-CL.piece=3M }\end{array}$

'I'll take out the boy's piece of meat (to his detriment).'

The marker -te (see Haude 2006: 405f.) is an applicative morpheme that derives indirective verbs. It indicates that there is an additional entity involved, with respect to which $\mathrm{T}$ is manipulated. ${ }^{11}$ Compare (45a) and (45b). In (45a), which contains the non-applicative verb, the OBV argument represents a participant that is directly affected by the event (a stick that is cut). In (45b), the applicative indicates that the event affects the relation between two entities: one entity, $\mathrm{T}$ (the stick), is manipulated with respect to another one, $\mathrm{G}$ (e.g. a tree). Example (45b) shows $\mathrm{T}$ expressed as an argument; example (46) shows both $\mathrm{T}$ and $\mathrm{G}$ overtly expressed, the former as an argument, the latter as an adjunct.

$$
\begin{array}{lll}
\text { a. } & \tan -n a=\varnothing \quad \text { as } & \text { kori:di } \\
\text { cut-DR=1SG } \quad \text { ART.N } & \text { stick } \\
\text { 'I cut the stick.' } &
\end{array}
$$

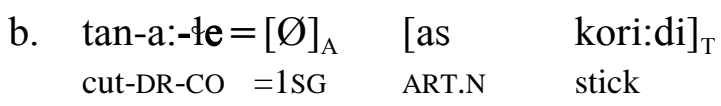

'I cut the stick off (e.g. a tree).'

$\begin{array}{lllll}\text { sit-a:-He }=[\varnothing]_{\mathrm{A}} & {[\text { kos }} & \text { siye:re }]_{\mathrm{T}} & {[\text { no-kos }} & \text { chor }]_{\mathrm{G}} \\ \text { sew-DR-CO }=1 \mathrm{SG} & \text { ART.N.AB } & \text { zip } & \text { OBL-ART.N.AB } & \text { shorts }\end{array}$

'I sewed the zip into the shorts.'

The applicative suffix - $p a$, which is not very productive, occurs in some three-participant expressions like chusa:pa 'show' (from chus- 'point at'), vata:pa 'teach' (from vat- '[make] appear') or kena:pa 'tell' (whose root, ken-, does not occur in other environments). The derivation is illustrated in the elicited examples (47a) and (47b). As (47b) shows, verbs containing this suffix are secundative, with $\mathrm{G}$ encoded as argument.

\footnotetext{
${ }^{10}$ First and second person are optionally encoded by a pronominal element preceding the verb; see Haude 2011.

${ }^{11}$ Some of the verbs listed in the previous sections contain the element $-\not e$, but they are not synchronically analyzable since the meaning of their root is not independently identifiable. In particular, the secundative verb kaya:te 'give', if historically derived by te, must be considered as fully lexicalized: firstly, while there is a verb root kay- 'eat', there is no evidence that this is synchronically the root of the verb kayate; secondly, if it were synchronically derived by the suffix $-\not e$, the verb would be expected to be indirective.
} 

a. $\quad[i 1]_{\mathrm{A}}$ chus-na $=[\varnothing]_{\mathrm{A}} \quad$ [us
alwaj $=\varnothing]_{\mathrm{T}}$
1 point_at-DR=1SG
ART.M
spouse $=1 \mathrm{SG}$
'I point at my husband.'

$\begin{array}{llll}\text { b. } \quad[\mathrm{il}]_{\mathrm{A}} & \text { chus-a:-pa }=[\emptyset]_{\mathrm{A}}--\left[{ }^{\prime} n \mathrm{e}\right]_{\mathrm{G}} & {[\mathrm{n}-\mathrm{uS}} & \text { alwaj=Ø }=\varnothing]_{\mathrm{T}} \\ 1 & \text { point_at-DR-APPL=1SG--3F } & \text { OBV-ART.M } & \text { spouse }=1 \mathrm{SG}\end{array}$

'I present my husband to her.'

The participant added by the causative suffix - poj is the causee, which can be characterized as $\mathrm{G}$ (i.e. not the participant affected by the caused action, but the one that is being told to carry it out). This additional participant is encoded as argument, while $\mathrm{T}$, the entity affected by the caused action, is encoded as adjunct. Hence, causativized verbs are secundative ( $G$ is an argument). Consider the underived verb in (48a) and its derived counterpart in (48b). ${ }^{12}$
a. loy if
ITN 1
leve:-na $=\varnothing$
as
wa:ka
'I'll chase the cow away.'

b. loy $[\mathrm{ij}]_{\mathrm{A}}$

leve-na-poj-na $=[\varnothing]_{\mathrm{A}}$
chase away DR-CAUS-DR=1SG

$\left[\begin{array}{ll}\text { at } & \mathrm{pa}: \mathrm{ko}\end{array}\right]_{\mathrm{G}}$
$[\mathrm{n}$-as
OBL-ART.N

wa:ka $]_{\mathrm{T}}$

'I'll have my dog chase away the cow.'

Causativized verbs as well as some verbs derived by the applicative suffix - $p a$ can be combined with an additional applicative suffix, -(n)as (glossed 'APPL2' for lack of a better term), which, without any apparent change in meaning, turns the verb into an indirective one. This is illustrated in (49) and (50).

$$
\begin{array}{lllll}
{[i 1]_{\mathrm{A}}} & \text { chus-a-pa:-nas }=[\emptyset]_{\mathrm{A}} & {[\mathrm{us}} & \text { alwaj }=\varnothing]_{\mathrm{T}} & {[\text { n-i'ne }]_{\mathrm{G}}} \\
1 & \text { point_at-DR-APPL-APPL2 }=1 \mathrm{SG} & \text { ART.M } & \text { my_spouse=1SG } & \text { OBL-PRO.3F }
\end{array}
$$

'I present my husband to her.'

$$
\begin{aligned}
& \begin{array}{llll}
\text { jayna } & \text { kiro' } & \text { leve-na-poj-as-na }=[\varnothing]_{\mathrm{A}} & {\left[\begin{array}{ll}
\text { kis } & \text { jokme }
\end{array}\right]_{\mathrm{T}}}
\end{array} \\
& \text { DSC DM.PL.AB chase_away-DR-CAUS-APPL2-DR=1SG ART.PL.AB bird } \\
& {[\text { ni-kinos a:na }=\varnothing]_{\mathrm{G}}} \\
& \text { OBL-ART.F.AB younger_sibling=1SG }
\end{aligned}
$$

The pragmatic function of the suffix $-(n) a s$ is not clear. In any case, the examples show that its use is not conditioned by the referential hierarchy that plays a role determining the argument frame of two-participant verbs. In (49), the suffix promotes a NP to argument status, while the pronoun (which expresses the more topical, i.e. previously introduced, participant) is an adjunct.

\footnotetext{
${ }^{12}$ On the double occurrence of the direct marker see Haude 2006: 96.
} 
In (50), the suffix promotes a non-human $\mathrm{T}$ argument status, while the human $\mathrm{G}$ is an adjunct. Even though animacy does not play a primary role in the hierarchy that determines argument encoding in Movima, human participants are usually treated as ranking higher than non-human participants. If the referential hierarchy played a role for the application of the suffix - $(n) a s$, it would be expected that the suffix be restricted to cases where T outranks G, so that the higherranking $\mathrm{T}$ participant can be expressed as the argument.

Finally, a strategy to create three-participant verbs that I wish to mention briefly is the incorporation of a nominal element or classifier. The verb remains transitive (on this type of incorporation see Haude 2006: 377ff.). Its argument frame is determined by the semantic role of the participant represented by the incorporated element. When the incorporated element represents $\mathrm{T}$, the verb is secundative, with the arguments $\mathrm{A}$ and $\mathrm{G}$; when the incorporated element represents $\mathrm{G}$, the verb is indirective, with the arguments $A$ and $T$. Consider the following examples. In (51), the incorporated element represents $\mathrm{T}$, i.e. the manipulated entity; the non- $\mathrm{A}$ argument (OBV) expresses G. In (52), the incorporated element represents $\mathrm{G}$ and the non-A argument expresses T. ${ }^{13}$

$$
\begin{array}{lll}
\text { loy } & {[\mathrm{il}]_{\mathrm{A}}} & \text { dol-a:-mi }=[\varnothing]_{\mathrm{A}} \\
\text { ITN } & 1 & \text { fill-DR-CL.water=1SG }
\end{array}
$$

[as

ART.N

'I'll fill the bucket with water.'

$$
\begin{array}{lll}
\text { loy } & {[\mathrm{i}]_{\mathrm{A}}} & \text { kon-a:-lo1 }=[\varnothing]_{\mathrm{A}} \\
\text { ITN } & 1 & \text { take_out-DR-CL.water }=1 \mathrm{SG}
\end{array}
$$

'I'll take my laundry out of the water.' [is $\quad$ dokwe $=\varnothing]_{\mathrm{T}}$

ART.PL clothes $=1 \mathrm{SG}$

To sum up, most valence-increasing mechanisms create secundative verbs; an exception is formed by the suffix -te 'co-participant' and by incorporated elements representing G. As was already apparent from the glosses of the verbs listed in (24) and (33), three-participant verbs in Movima are often derived or seem to stem from morphologically complex historical sources. Even though the present analysis is not based on an exhaustive database, neither in terms of types nor of tokens, it suggests that involvement of a third participant in Movima is in general established by overt morphology; this question requires further research, however, involving an analysis of both the lexicon and of text frequency.

\section{Conclusion}

The expression of three-participant events in Movima shows two major characteristics: firstly, three-participant events are expressed by monotransitive verbs, which take one non-A participant as an argument, while the other non-A participant is optionally expressed as an adjunct. Secondly, the choice of which of the two non-A participants is selected as the verb's argument ( $T$ or $G$ ), is lexically or, in the case of derived verbs, morphologically determined. The first

\footnotetext{
${ }^{13}$ The classifiers - $m i$ and -loł both mean 'water': - $m i$ is used for water as a manipulable entity (e.g. for drinking), -lot for water as a fixed entity (e.g. in a lake). For the verb kona:lot in (52) there exists a simple form, kon-na (take_outDR), which also has T in the core: kon-na= $\emptyset$ is dokwe 'I'll take my laundry out (of sth.).' The verb dola:mi in (51), however, never occurs without the classifier representing T (see Haude 2006: 388ff.); for the time being, there is no evidence that this strategy to express three-participant events can change the argument frame of the verb.
} 
finding is relevant because the discussion of three-participant event expressions in the linguistic literature generally focuses on predicates with three syntactic arguments (Margetts and Austin 2007 being a notable exception); the case of Movima shows that, in order to capture the variety of ways in which three-participant events can be expressed, the scope has to be extended to languages that do not have such ditransitive verbs. The second finding is relevant in the context of the interaction between three-participant event expressions and referential hierarchies. Since the encoding of the syntactic arguments of transitive predicates in Movima is determined by a referential hierarchy, it may seem striking that the hierarchy plays no role in the assignment of argument status of verbs denoting three-participant events. Apparently, only the opposition between an Agent (actor) and a non-Agent (undergoer) is sensitive to the hierarchy; whichever non-Agent is selected as argument by the verb, is encoded depending on its hierarchical relation with respect to the Agent alone.

\section{Symbols and Abbreviations}

= internal clitic, -- external clitic,$<>$ infix, $\sim$ reduplication

1=first person; $2=$ second person; $3=$ third person; $\mathrm{AB}=$ absential; $\mathrm{ADJCT}=$ adjunct; $\mathrm{AGT=agentive;}$ APPL=applicative; APPL2=applicative 2; ART=article; $\quad$ BEN=benefactive; CAUS=causative; $\mathrm{CL}=$ classifier; $\mathrm{CO}=$ co-participant; $\mathrm{DR}=$ direct; $\mathrm{DSC}=$ discontinuous; $\mathrm{DUR}=$ durative; $\mathrm{F}=$ feminine; FRUST=frustrative; FUT=future; HAB=habitual; INAL=inalienable; INSTR=instrument; INV=inverse; ITN=intentional; $\mathrm{LV}=$ linking vowel; $\mathrm{M}=$ masculine; $\mathrm{MAL}=$ malefactive; $\mathrm{MOD}=$ modal; $\mathrm{MOV}=$ moving; $\mathrm{N}=$ neuter; $\mathrm{NMZ}=$ nominalizer; $\mathrm{NP}=$ noun phrase; $\mathrm{NSTD}=$ nonstanding; $\mathrm{OBL}=$ oblique; $\mathrm{OBV}=\mathrm{obviative;}$ $\mathrm{OBV}=$ obviative argument; $\mathrm{PL}=$ plural; $\mathrm{PRED}=$ predicate; $\mathrm{PRO}=$ free pronoun; $\mathrm{PROX}=$ proximate argument; $\mathrm{PST}=$ past; R/R=reflexive; REAS=reason; REL=relative; RES=resultative; $\mathrm{SG}=$ singular; TOP=topic position

\section{References}

Bickel, Balthasar. 2010. Grammatical relations typology. The Oxford Handbook of Linguistic Typology, ed. by Jae-Jung Song, 399-444. Oxford: Oxford University Press.

Haspelmath, Martin. 2005. Argument marking in ditransitive alignment types. Linguistic Discovery 3/1.1-21.

Haude, Katharina. 2006. A grammar of Movima. $\mathrm{PhD}$ dissertation, Radboud Universiteit Nijmegen. (Available at http://webdoc.ubn.ru.nl/mono/h/haude_k/gramofmo.pdf.)

-----. 2010. The intransitive basis of Movima clause structure. Ergativity in Amazonia, ed. by Spike Gildea and Francesc Queixalós, 285-315. Amsterdam/Philadelphia: John Benjamins.

-----. 2011. Argument encoding in Movima: the local domain. International Journal of American Linguistics 77/4.559-575

-----. 2012. Saillance inhérente et saillance discursive en movima. Faits de Langues 39:169-180.

Malchukov, Andrej, Martin Haspelmath, and Bernard Comrie. 2010. Ditransitive constructions: a typological overview. Studies in Ditransitive Constructions. A Comparative Handbook, ed. by Andrej Malchukov, Martin Haspelmath and Bernard Comrie, 1-63. Berlin: Mouton de Gruyter.

Margetts, Anna and Peter Austin. 2007. Three-participant events in the languages of the world: towards a cross-linguistic typology. Linguistics 45/3.393-452.

Van Valin, Robert D. junior, and Randy J. LaPolla. 1997. Syntax: Structure, Meaning and 
Function. Cambridge: Cambridge University Press.

Witzlack-Makarevich, Alena, Balthasar Bickel, Lennart Bierkandt and Taras Zakharko. In preparation. Alignment across the lexicon. Ms. University of Zurich.

Author's Contact Information:

Katharina Haude

haude@vjf.cnrs.fr 